Original Research

\title{
The Influence of Diabetic Foot Exercise in Sensory Peripheral Neuropathy with Monofilament Test on Diabetes Mellitus Clients
}

\section{Tintin Sukartini, Candra Panji Asmoro and Putri Nandani Alifah}

Faculty of Nursing, Universitas Airlangga, Surabaya, Indonesia

\section{ABSTRACT}

Background: Peripheral neuropathy is a long-term complication that attacks the nerves and loses the sensation of protection which affects about $50 \%$ of people with diabetes mellitus (DM). Diabetic foot exercises can help blood circulation, especially in the legs or lower limbs. This researched aimed to analyze the effect of diabetic foot exercise on sensory peripheral neuropathy in DM clients.

Method: The study design used quasi-experimental pre-post test with control group. Samples were 28 respondents using purposive sampling and divided into two groups of 14 respondents each. The independent variable is diabetic foot training, and the dependent variable is peripheral sensory neuropathy. Interventions are carried out 3 times a week for 4 weeks. The research instrument was Weinstein Monofilament $10 \mathrm{~g}$ Semmes and a diabetic foot training checklist. Data analysis using the Wilcoxon-signed rank test and Mann Whitney test with $\alpha \leq 0.05$.

Result: The Wilcoxon-signed rank test in the treatment group showed differences in sensory peripheral neuropathy after treatment $(p=0,000)$ and no difference in the control group $(\mathrm{p}=0.564)$. The Mann Whitney test results showed differences in sensory peripheral neuropathy between the treatment group and the control group after treatment $\mathrm{p}=0.039$.

Conclusion: Diabetic foot exercises can be used as an alternative measure to improve sensory peripheral neuropathy.
\end{abstract}

\section{ARTICLE HISTORY}

Received: Dec 26, 2019

Accepted: Dec 31, 2019

\section{KEYWORDS}

sensory peripheral neuropathy; diabetic foot exercises; monofilament test

\section{CONTACT}

Tintin Sukartini

\tintin-s@fkp.unair.ac.id

$\doteq$ Faculty of Nursing Universitas

Airlangga, Surabaya, Indonesia

Cite this as: Sukartini, T., Asmoro, C. P., \& Alifah, P. N. (2019). The Influence of Diabetic Foot Exercise in Sensory Peripheral Neuropathy with Monofilament Test on Diabetes Mellitus Clients. Jurnal Ners, 14(3si), 340-344. doi:http://dx.doi.org/10.20473/jn.v14i3(si).17263

\section{INTRODUCTION}

International Diabetes Federation (IDF) in 2017 stated that Indonesia ranks 6th in the number of diabetics in the world (Nam Han Cho., 2017). In 2017 the number of diabetics in Indonesia reached 10.3 million people and among them $73.7 \%$ were unaware that they had diabetes. The prevalence of diabetes mellitus (DM) in Indonesia has reached 9.1 million people. IDF estimates that the number of diabetics in Indonesia will continue to soar to reach 16.7 million in 2045 (PERKENI, 2015).

Increased prevalence of DM patients can increase complications such as heart disease, nephropathy, retinopathy, diabetic foot injury, and neuropathy. Neuropathy is one of the long-term complications that affects about $50 \%$ of people with diabetes. Peripheral neuropathy is a broad and potentially disabling pathological condition that includes more than 100 different forms and manifestations of nerve damage. The diverse pathogenesis of peripheral neuropathy affects autonomic, motor and / or sensory neurons, and symptoms that describe these conditions are abnormal skin sensations, muscle dysfunction and, especially, chronic pain (Dobson, McMillan, \& Li, 2014). Neuropathy is strongly associated with the duration and severity of hyperglycemia. Disease prevalence increases with increasing duration of DM and poor glycemic control (Chawla, Chawla, \& Jaggi, 2016).

About 11.9 million adults in the United States aged $>40$ years have been diagnosed with diabetes and among them, 3.9 million $(32.7 \%)$ have diabetes neuropathy and 1.6 million (13.1\%) have comorbid neuropathy and retinopathy (Ahmad \& Mittal, 2015). 
The prevalence of diabetic peripheral neuropathy ranges from $16 \%$ to $66 \%$. Amputation in diabetics is 10 to 20 times more common than non-diabetes (Federation, 2017). Patients with diabetic neuropathy are more often hospitalized than other diabetes complications. Diabetic neuropathy increases in patients within 5-10 years after the onset of this disease. Diabetic peripheral neuropathy (DPN) has a strong association with other complications such as diabetic retinopathy (67\% versus $21 \%$ ) and micro albuminuria (51\% vs $41 \%)$. It has been observed that $56 \%$ of patients with DM less than 5 years have moderate / severe DPN (Chawla et al., 2016). As many as 1,785 DM patients in 2008 to 2009 in Indonesia experienced $63.5 \%$ of neuropathy complications, $42 \%$ diabetic retinopathy, $73 \%$ nephropathy, $16 \%$ spectacular, and $27.6 \%$ microvascular complications (Soewondo et al., 2010). Research in Persadia Units at dr. Soetomo Hospital Surabaya showed that $30.8 \%$ of 26 respondents who did not experience diabetes ulcers complained of neuropathy (Widyawati, Irawaty, \& Sabri, 2010). One of the factors that trigger diabetic foot ulcers is neuropathy. International Diabetes Federation reports that 1 in 6 diabetics will experience diabetes ulcers during their lifetime (International Diabetes Federation, 2017). Diabetic foot exercises are activities or exercises carried out by DM patients to help blood circulation, especially in the legs or lower leg (Francia, Gulisano, Anichini, \& Seghieri, 2014).

Based on a preliminary study at the Gedongan Community Health Center in Mojokerto, East Java, DM was included in the list of the 10 biggest diseases in the last 3 years. People with DM every year always experience an increase, in 2015 there were 2,434 patients, in 2016 there were 3,085 patients, in 2017 there were 3,343 patients. In March 2018 there were 32 DM patients with neuropathy. Observations and interviews during preliminary studies with outpatients at the Gedongan Community Health Center with DM showed that 7 out of 12 patients complained of frequent leg pain, calluses, and dry feet. The Gedongan Community Health Center in Mojokerto has not yet intervened specifically in diabetic neuropathy to reduce the incidence of foot ulcers. The intervention given to DM patients is to schedule control patients, health education, and antidiabetes drugs on a regular basis according to the doctor's advice.

Most cases of peripheral neuropathy cannot be fully treated because the underlying cause is unknown or incurable, so the main goal associated with the treatment of most forms of peripheral neuropathy is to control or correct troublesome symptoms (Nathan, 2014). Exercise is known to increase several metabolic factors that can affect nerve health (Nimmo, Leggate, Viana, \& King, 2013). Based on previous reviews, researchers were interested in conducting research on the effects of diabetic foot exercise on sensory peripheral neuropathy in DM patients at Gedongan Health Center, Mojokerto City.

\section{MATERIALS AND METHODS}

The research design used was quasy experiment (prepost test with control design) and the project was approved by the Health Research Ethics Committee of Faculty of Nursing Universitas Airlangga (ethical number 989-KEPK). The sample in this study was DM clients at Gedongan Health Center, Mojokerto. The sample size in this study were 28 clients who were divided into two groups. The sampling technique used in this study was purposive sampling. The instrument used was a $10 \mathrm{~g}$ monofilament type type diabetes test Semmes-Weinstein monofilament neuropathy measuring $10 \mathrm{~g}$ with a thickness of 5.07 and a checklist for diabetic foot exercises.

Retrieval of data in this study was conducted at Gedongan Community Health Center, Mojokerto City, then followed up and routinely intervened through clients' home visits. Samples were divided into treatment groups and the controls were matched pairs. The researcher explained the objectives, benefits, procedures, and research time in detail to the respondents. After that, the researchers asked the respondents for their consent to participate by signing an agreement letter in the study. At the first home visit the researchers conducted a pre test to determine the initial value of the dependent variable by examining the value of sensory neuropathy using a $10 \mathrm{~g}$ monofilament device in the treatment and control groups. Foot gymnastics interventions were carried out every $3 \mathrm{x}$ / week for 4 weeks, referring to Harmaya (2014) in the treatment group while intervention was not carried out in the control group (Harmaya, Sukawana, \& Lestari, 2014). At the end of the fourth week the researchers conducted a post test to determine the final value of the dependent variable, namely the value of sensory peripheral neuropathy with $10 \mathrm{~g}$ monofilament in the tre

The research analysis was carried out with the help of SPSS v16 software. Bivariate analysis used the Mann Whitney Test statistical test using the degree of significance $\alpha \leq 0.05$ to compare the results of the treatment and control groups. The Wilcoxon signed rank statistical test compared the results of the pretest and posttest in the intervention group and the control group.

\section{RESULT}

Most of the respondents were women (71.4\%). The majority of respondents were in the range of the early elderly and the late elderly (92.85\%); age of 46-55 years (46.43\%) and age 56-65 (46.43\%). Most of the patients who participated in this study were diagnosed for less than 5 years (39.28\%). Most of them do not have job (46.43\%).

In the treatment group before diabetic foot exercise, the average value of sensory peripheral neuropathy was 2.64 , which meant that the DM patients in the treatment group had sensory 
Table 1. Characteristics of Respondents

\begin{tabular}{|c|c|c|c|c|}
\hline \multirow[t]{2}{*}{ Characteristics of Respondents } & \multicolumn{2}{|c|}{$\begin{array}{c}\text { Treatment Group } \\
(\mathrm{n}=14)\end{array}$} & \multicolumn{2}{|c|}{$\begin{array}{c}\text { Control Group } \\
(\mathrm{n}=14)\end{array}$} \\
\hline & $\mathrm{n}$ & $\%$ & $\mathrm{n}$ & $\%$ \\
\hline \multicolumn{5}{|l|}{ Gender } \\
\hline Men & 4 & 28,6 & 4 & 28,6 \\
\hline Woman & 10 & 71,4 & 10 & 71,4 \\
\hline \multicolumn{5}{|l|}{ Age } \\
\hline $36-45$ years & 0 & 0,0 & 2 & 14,3 \\
\hline $46-55$ years & 9 & 64,3 & 4 & 28,6 \\
\hline $56-65$ years & 5 & 35,7 & 8 & 57,1 \\
\hline \multicolumn{5}{|l|}{ Duration diagnosed with DM } \\
\hline$<5$ years & 5 & 35,7 & 6 & 42,9 \\
\hline $5-10$ years & 5 & 35,7 & 2 & 14,3 \\
\hline$>10$ years & 4 & 28,6 & 6 & 42,9 \\
\hline \multicolumn{5}{|l|}{ Profession } \\
\hline Do not have job & 8 & 57,1 & 5 & 35,7 \\
\hline Pensionary & 1 & 7,1 & 2 & 14,3 \\
\hline Civil servants & 1 & 7,1 & 2 & 14,3 \\
\hline Entrepreneur & 3 & 21,4 & 2 & 14,3 \\
\hline Other & 1 & 7,1 & 3 & 21,4 \\
\hline
\end{tabular}

Table 2. Sensory Peripheral Neuropathy Before and After Diabetic Foot Exercises in the Treatment and Control Groups

\begin{tabular}{lccccc}
\hline \multirow{2}{*}{ Groups } & \multicolumn{2}{c}{ Mean } & p value Wilcoxon signed rank & \multicolumn{2}{c}{ p value Mann-Whitney test } \\
\cline { 2 - 3 } \cline { 5 - 6 } Pretest & Posttest & test & 0 & Pretest & Posttest \\
\hline Treatment group & 2,64 & 1,64 & 0,541 & 0,039 \\
Control group & 2,57 & 2,64 & 0,564 & & \\
\hline
\end{tabular}

peripheral neuropathy on average. After diabetic foot exercise, the mean sensory peripheral neuropathy showed a decrease to 1.64 , meaning that sensory peripheral neuropathy scores improved. The results of statistical tests showed that there were significant differences between the values of sensory peripheral neuropathy before and after diabetic foot exercise in the intervention group ( $p=0,000)$ while in the control group it meant that there were no differences in sensory peripheral neuropathy ( $p=0.564)$. Whereas in the post-intervention results there were differences in sensory peripheral neuropathy between the treatment and control groups ( $\mathrm{p}=$ 0.039).

\section{DISCUSSION}

Patients with diabetes and neuropathy are associated with low nerve conduction due to demyelination and loss of large myelin fibers, and decreased potential for nerve action due to loss of axons (Charles et al., 2010; Kobori et al., 2017). In patients with peripheral diabetic neuropathy, loss of sensation in the foot causes recurrent minor injuries (calluses, nails, foot deformities) or external causes (shoes, burns, foreign objects) that are not detected at that time and consequently can cause foot ulceration. This can be followed by ulcer infection, which can eventually cause amputation of the foot, especially in patients with peripheral arterial disease (Alexiadou \& Doupis,
2012). In diabetic patients, regular physical activity reduces weight, increases blood glucose control and insulin sensitivity which all lead to a reduced risk of developing neuropathy (Francia et al., 2014).

The results of this study indicate that diabetic foot exercise can reduce sensory peripheral neuropathy. Exercise positively influences other pathological factors associated with diabetic peripheral neuropathy, by promoting microvascular function and fat oxidation, by reducing oxidative stress and increasing neurotropic factors (Colberg et al., 2010; Kluding et al., 2012). Exercise-induced Neurotrophin3 (NT3) increases are associated with increased peripheral nerve conduction velocity and reduction in neuropathic pain (Li et al., 2012). Neurotrophin-3 (NT-3) is known to promote the survival and differentiation of existing neurons and to encourage the growth of new synapses and neurons.

Foot and toes exercises are one of the exercises that can modulate the level of sorbitol in the body so as to prevent a decrease in blood flow in the endoneural blood flow (Dixit, Maiya, \& Shastry, 2014). Providing stimulation in the form of exercise or leg exercises can produce potential action resulting in depolarization which results in increased $\mathrm{Na}+/ \mathrm{K}$ + ATP activity, axonal transport is increased, patients feel sensory sensations / sensory responses. Foot exercises can help smooth and improve blood circulation in the legs. It also helps in the process of wound healing in diebetes foot ulcer (Eraydin \& 
Avşar, 2018). In addition to this effect, the main reason for a large increase in blood flow during exercise is a decrease in oxygen in the tissues, which is one of the chemical factors found in diabetic patients. The decrease in oxygen causes dilation because of its direct effect on muscle arterioles. Muscles consume oxygen quickly during exercise, and the amount of oxygen in the tissue decreases. In the absence of oxygen, the arteriolar wall cannot continue to contract, and lack of oxygen causes the release of vasodilators. This causes vasodilation of local arterioles so that all capillaries are open and blood flow increases. Blood circulation that smoothly carries oxygen and nutrients to the tissues and nerve cells that will affect the metabolic process of Schwann cells so that axon function can be maintained. The optimal function of nerve cells in DM patients will maintain sensory function of their feet (Han, Sin, \& Yoon, 2013).

Foot exercises play a role in controlling blood glucose levels to improve peripheral blood circulation which can be seen from the value of the Ankle Brachial Index (ABI) in DM patients (Barone Gibbs, Dobrosielski, Althouse, \& Stewart, 2013). Decreasing glucose levels in the blood will improve myelin nerve function and axons so that DM patients will be able to feel pain, heat, vibration, and pressure. In other words, the nerve endings of patients experience increased conduction and recurrent sensitivity in protection against risky conditions, which are detected by examining the sensation of protection using monofilament $10 \mathrm{~g}$..

\section{CONCLUSION}

DM patients who perform foot exercises will experience a decrease in the value of peripheral sensory neuropathy because foot exercise movements can improve myelin nerves and axon function so that nerve endings undergo improved conduction and sensitive return detected by monofilament $10 \mathrm{~g}$. There was a decrease in sensory peripheral neuropathy in the intervention group and there was no decrease in the value of sensory peripheral neuropathy in the control group proving the theory above that foot exercise can help smoothen so as to improve blood circulation and sensitivity to prevent numbness. Community health nurses can provide education about foot exercise to DM patients, especially patients with peripheral neuropathy. DM patients are able to do leg exercises independently at home to improve the status of sensory peripheral neuropathy so that it can prevent the occurrence of ulcers.

\section{REFERENCES}

Ahmad, S., \& Mittal, M. (2015). Diabetic Neuropathies. JIMSA, 28(1), 51-53.

Alexiadou, K., \& Doupis, J. (2012). Management of Diabetic Foot Ulcers. Diabetes Ther, 3(4). https://doi.org/10.1007/s13670-015-0133-x
Barone Gibbs, B., Dobrosielski, D. A., Althouse, A. D., \& Stewart, K. J. (2013). The effect of exercise training on ankle-brachial index in type 2 diabetes. Atherosclerosis, 230(1), 125-130. https://doi.org/10.1016/j.atherosclerosis.2013.0 7.002

Charles, M., Soedamah-Muthu, S. S., Tesfaye, S., Fuller, J. H., Arezzo, J. C., Chaturvedi, N., \& Witte, D. R. (2010). Low peripheral nerve conduction velocities and amplitudes are strongly related to diabetic microvascular complications in type 1 diabetes: The EURODIAB prospective complications study. Diabetes Care, 33(12), 26482653. https://doi.org/10.2337/dc10-0456

Chawla, A., Chawla, R., \& Jaggi, S. (2016). Microvasular and macrovascular complications in diabetes mellitus: Distinct or continuum? Indian Journal of Endocrinology and Metabolism, Vol. 20, pp. 546553. https://doi.org/10.4103/22308210.183480

Colberg, S. R., Sigal, R. J., Fernhall, B., Regensteiner, J. G., Blissmer, B. J., Rubin, R. R., ... Braun, B. (2010). Exercise and type 2 diabetes: The American College of Sports Medicine and the American Diabetes Association: Joint position statement. Diabetes Care, 33(12). https://doi.org/10.2337/dc10-9990

Dixit, S., Maiya, A. G., \& Shastry, B. A. (2014). Effect of aerobic exercise on peripheral nerve functions of population with diabetic peripheral neuropathy in type 2 diabetes: A single blind, parallel group randomized controlled trial. Journal of Diabetes and Its Complications, 28(3), 332-339. https://doi.org/10.1016/j.jdiacomp.2013.12.006

Dobson, J. L., McMillan, J., \& Li, L. (2014). Benefits of exercise intervention in reducing neuropathic pain. Frontiers in Cellular Neuroscience, 8(1 APR), 1-9. https://doi.org/10.3389/fncel.2014.00102

Eraydin, Ş., \& Avşar, G. (2018). The Effect of Foot Exercises on Wound Healing in Type 2 Diabetic Patients With a Foot Ulcer. Journal of Wound, Ostomy and Continence Nursing, 45(2), 123-130. https://doi.org/10.1097/won.00000000000004 05

Federation, I. D. (2017). IDF Diabetes Atlas Eighth: Eighth edition 2017. In International Diabetes Federation. IDF Diabetes Atlas, 8th edn. Brussels, Belgium: International Diabetes Federation, 2017. http://www.diabetesatlas.org (8th ed.). https://doi.org/http://dx.doi. org/10.1016/S0140-6736(16)31679-8.

Francia, P., Gulisano, M., Anichini, R., \& Seghieri, G. (2014). Diabetic Foot and Exercise Therapy: Step by Step The Role of Rigid Posture and Biomechanics Treatment. Current Diabetes Reviews, 10(2), 86-99. https://doi.org/10.2174/157339981066614050 7112536

Han, J. W., Sin, M. Y., \& Yoon, Y. S. (2013). Cell therapy for diabetic neuropathy using adult stem or progenitor cells. Diabetes and Metabolism Journal, 
$37(2)$,

91-105. https://doi.org/10.4093/dmj.2013.37.2.91

Harmaya, D. P., Sukawana, I. W., \& Lestari, M. (2014). Pengaruh Masase Kaki Terhadap Sensasi Proteksi Pada Kaki Pasien Diabetes Melitus Tipe Ii Dengandiabetic Peripheral Neuropathy. COPING (Community of Publishing in Nursing), 2(3).

International Diabetes Federation. (2017). IDF Diabetes Atlas 8th Edition. Brussels, Belgium.

Kluding, P. M., Pasnoor, M., Singh, R., Jernigan, S., Farmer, K., Rucker, J., ... Wright, D. E. (2012). The effect of exercise on neuropathic symptoms, nerve function, and cutaneous innervation in people with diabetic peripheral neuropathy. Journal of Diabetes and Its Complications, 26(5), 424-429. https://doi.org/10.1016/j.jdiacomp.2012.05.007

Kobori, M., Yagihashi, S., Shiina, N., Shiozawa, N., Haginoya, A., Ojima, M., ... Osonoi, T. (2017). Fouryear sequential nerve conduction changes since first visit in Japanese patients with early type 2 diabetes. Journal of Diabetes Investigation, 8(3), 369-376. https://doi.org/10.1111/jdi.12583

Li, H., Shen, Z., Lu, Y., Lin, F., Wu, Y., \& Jiang, Z. (2012). Muscle NT-3 levels increased by exercise training contribute to the improvement in caudal nerve conduction velocity in diabetic rats. Molecular Medicine Reports, 6(1), 69-74. https://doi.org/10.3892/mmr.2012.897

Nam Han Cho. (2017). Eighth edition 2017. In IDF Diabetes Atlas, 8th edition. https://doi.org/http://dx.doi.

org/10.1016/S0140-6736(16)31679-8.
Nathan, D. M. (2014). The diabetes control and complications trial/epidemiology of diabetes interventions and complications study at 30 years: Overview. Diabetes Care, 37(1), 9-16. https://doi.org/10.2337/dc13-2112

Nimmo, M. A., Leggate, M., Viana, J. L., \& King, J. A. (2013). The effect of physical activity on mediators of inflammation. Diabetes, Obesity \& Metabolism, 15 Suppl 3, 51-60. https://doi.org/10.1111/dom.12156

PERKENI. (2015). Pengolahan dan Pencegahan Diabetes Melitus Tipe 2 Di Indonesia 2015. https://doi.org/10.1017/CB09781107415324.0 04

Soewondo, P., Soegondo, S., Suastika, K., Pranoto, A., Soeatmadji, D. W., \& Tjokroprawiro, A. (2010). The DiabCare Asia 2008 study - Outcomes on control and complications of type 2 diabetic patients in Indonesia. Medical Journal of Indonesia, 235. https://doi.org/10.13181/mji.v19i4.412

Widyawati, I. Y., Irawaty, D., \& Sabri, L. (2010). Latihan Active Lower Range of Motion Menurunkan Tanda dan Gejala Neuropati Diabetikum. Jurnal Ners, 5(2), 107-117 